\title{
Спосіб виявлення пожеж на території полігону твердих побутових відходів
}

\author{
Н.В. Рашкевич ${ }^{1}$, І.А. Черепньов ${ }^{2}$, І.О. Ковальов ${ }^{3}$ \\ ${ }^{1}$ Національний університет цивільного захисту України (м. Харків, Україна), \\ e-mail: nine291085@gmail.com \\ ${ }^{2}$ Харківський національний технічний університет сільського господарства \\ ім. П. Василенка (м. Харків, Україна), e-mail: voenpred314@ukr.net \\ 3 Військовий інститут танкових військ Національного технічного університету
} «Харківський політехнічний інститут» (м. Харків, Украӥна), e-mail: tom_1972@ukr.net

У ході роботи відмічена техногенна небезпека полігонів твердих побутових відходів (ТПВ), яка пов'язана з виникненням поверхових та підповерхневих пожеж. Для своєчасного попередження виникнення та поширення пожежі потрібно визначати горіння не тільки на поверхні, а й всередині тіла полігону. Встановлено, що існуючі способи виявлення інформаційних ознак пожежі при несприятливих метеорологічних або надзвичайних умовах характеризуються низькою оперативністю, достовірністю, повнотою.

Запропоновано спосіб виявлення пожеж на території полігону ТПВ. Спосіб реалізується за допомогою тепловізійної камери, відеокамери, мікрохвильового радіометру, які розташовуються паралельно один одному на вишці з можливістю панорамного огляду. Результати спостереження приладів в різних спектральних діапазонах довжин хвиль спільно з даними кутового-азимутального вимірювача напрямку осей надходять до головного серверу, де шляхом накладання та співставлення підлягають фільтруванню та виключенню теплових перешкод. Виключення теплових перешкод та використання, як мінімум двох точок спостереження, підвищують вірогідність виявлення осередків горіння. Таким чином, реалізація запропонованого способу забезпечує в автоматичному режимі виявлення осередків пожеж на ранній стадії їхнього виникнення та інформаційну підтримку прийняття управлінських рішень локалізації та ліквідації фракторів небезпек із мінімальним впливом на довкілля та людей.

Ключові слова: пожежа, полігон твердих побутових відходів, дистанційні прилади спостереження, тепловізійна камера, відеокамера, мікрохвильовий радіометр.

Постановка проблеми. На території України в результаті життєдіяльності людини щороку утворюються значні обсяги твердих побутових відходів (ТПВ). Для нашої держави загальною тенденцією є низький рівень безпечної утилізації та високий показник видалення їх на звалища та спеціальні полігони.

У 2017 році лише 6,6 \% утворених ТПВ було перероблено, в тому числі: 2,53 \% (1,31 млн. м³) спрямовані на заготівельний пункт вторинної сировини, 1,63\% (0,85 млн. м $\left.{ }^{3}\right)$ - сміттєпереробні підприємства, 2,48 \% (1,29 млн. м³) - сміттєспалювальні заводи, та 0,0072 \% (3 750,2 м³) - компостовані. Решта (а це майже 94 \%) підлягали видаленню на звалища та полігони, яких станом на 2017 рік в Україні налічувалось 5434 одиниць. 3 них 309 одиниць (5,68\%) є перевантаженими,
1347 одиниць (24,78 \%) - не відповідають нормам екологічної безпеки. Лише на 57 (1,05 \%) полігонах наявна система збирання фільтрату, в тому числі: на 40 полігонах наявна система знезараження фрільтрату, на інших 17 - влаштовані резервуари накопичувачі, колодязі або лотки, звідки періодично фільтрат транспортується на очисні споруди. На 13 (0,24 \%) полігонах влаштовано систему вилучення біогазу, з них: на 6 полігонах біогаз факельно спалюється, на 8 - експлуатуються когенераційні установки [1].

Місця видалення відходів, де внаслідок біохімічних процесів розкладання ТПВ утворюється широкий спектр екологічно-небезпечних речовин, створюють додаткове техногенне навантаження на довкілля. Продукти розкладання у вигляді фрільтраційних вод, полігонного газу мігру- 
ють в ґрунти, атмосферне повітря, поверхневі та підземні води, забруднюючи їх та створюючи загрозу інфекційних захворювань, отруєнь людей, тварин, ураження рослин хворобами та шкідниками [2].

Найбільш масштабні забруднення навколишнього середовища та виникнення підвищеної небезпеки для життєдіяльності людини відбуваються внаслідок надзвичайних подій (ситуацій), що пов'язані з пожежами, вибухами тощо. Наслідки горіння ТПВ та ліквідації пожежі призводять до наявності в екосистемі шкідливих (забруднюючих) речовин понад гранично допустимі концентрації, що провокує погіршення стану здоров'я серед робітників об'єкту, ліквідаторів пожежі та мешканців прилеглих населених пунктів. В процесі горіння (тління) окрім високих температур, токсичних продуктів, виникають зміни в тілі полігону, що характеризуються утворенням пустот, зсувів.

До резонансних надзвичайних ситуацій останніх років на полігонах ТПВ можна віднести об'єкти у м. Коломбо, (Шрі-Ланка, 2017 рік), м. Аддис-Абеба (Ефіопія, 2016 рік), с. Великі Грибовичі (Львівська область, Україна, 2016 рік), м. Гватемала (Республіка Гватемала, 2016 рік).

В Україні статистичні дані про виникнення пожеж та інших надзвичайних ситуацій мають неповний характер. Це пов'язано з недосконалістю програм обліку та реєстрації пожеж. Однак, наявного матеріалу [3-6] достатньо щоб стверджувати про наявність проблеми зі своєчасного та точного виявлення осередків небезпек.

Аналіз останніх досліджень і публікацій. Для виявлення пожеж використовують різні інформаційні ознаки: підвищену температуру, викиди газоподібних продуктів горіння, димові шлейфи та ін.

В умовах зростаючого антропогенного впливу дистанційні прилади спостереження, що представлені аерокосмічними та геофізичними методами на основі властивостей електромагнітних хвиль різного діапазону, надають не тільки ефективну інформацію про стан небезпеки об'єкту, але й вказують на осередки її виникнення та подальший розвиток. Хвилі взаємодіють з інформаційними ознаками пожежі і переносять отримані данні до датчиків. Датчики можуть бути встановлені як на поверхні землі (мобільні або стаціонарні вишки), так і у повітрі (на борту літака, аеростата, безпілотного літального апарату (БПЛА), або у космосі (на борту штучного супутника Землі) [7].

Відомий спосіб відеоспостереження відкритого простору з контролем пожежної небезпеки, в основу якого покладена рання діагностика пожежі по димових слідах та потокам повітря. Відповідно до способу проводять відеомоніторинг території, що охороняється, виділяють на вихідному зображенні рухливі області, порівнюють ці області із зразковими зображеннями з бібліотеки образів та приймають рішення про загоряння на підставі подібності отриманого та наявного зображень [8]. Застосування розглянутого рішення на території полігону ТПВ має низьку ефективність за початковою стадією виявлення небезпеки, місцем та видом горіння при несприятливих метеорологічних умовах навколишнього середовища.

Найбільш розповсюдженим прийнято вважати спосіб раннього виявлення загорянь на основі аналізу інтенсивності відбитого лазерного випромінювання, який заснований на оцінюванні теплових збурень повітря, що з'являються при виникненні загорянь [9]. Недоліком цього технічного рішення $є$ також висока ймовірності отримання хибних та несвоєчасних результатів внаслідок несприятливих метеорологічних умов. Спосіб не розрахований на локацію підповерхневого (скритого) горіння.

Відомий спосіб виявлення пожеж з космосу за отриманою інформацією про нагріті при температурі пожежі атмосферних газів в інфрачервоному діапазоні спектра в вікнах прозорості атмосфери шляхом зондування підстилаючої поверхні Землі [10]. До недоліків слід віднести низьку оперативність виявлення початкової стадії пожежі (малі джерела не підлягають локації), сильну залежність від метеорологічних умов, невисоку періодичність отримання даних зондування (особливо коли існують потреби у повторній зйомці зони небезпеки). Супутниковий моніторинг характеризується повною автоматизацією процесу отримання даних та легкою доступністю до них, але, в силу своєї невисокої деталізації, як правило, корисний для отримання загальної картини.

Також наявний спосіб виявлення пожеж шляхом спостереження у оптичному та інфрачервоному діапазонах за допомогою нерухомого прив'язного аеростату та наземної станції спостереження [11]. Недоліком вказаного технічного рішення $€$ вплив метеорологічних умов на стан розміщення аеростату відносно земної поверхні, а також недостатня інформативність способу, що пов'язана 3 неможливістю встановити зони горіння в товщі відходів за результатами спостереження у оптичному та інфрачервоному діапазонах.

Відомий спосіб виявлення пожеж на полігонах ТПВ з використанням БПЛА, який має блок спостереження в оптичному і інфрачервоному діапазонах, блок мікрохвильової радіометрії, що дозволяє забезпечувати покриття всієї площі полігону та визначати нові параметри осередку спалахування у зоні горіння. БПЛА має можливість
ISSN 2311-1828

http://enm.khntusg.com.ua
Інженерія природокористування, 2019, №3(13), с. 102 - 109

Engineering of nature management, 2019, \#3(13), p. 102 - 109 
як вільного переміщення у горизонтальній та вертикальній площині, так і має властивість зависати у повітрі безпосередньо над поверхнею 3 прив'язкою до точки спостереження [12].

Україна має потужній потенціал для розробки БПЛА [13], а спеціалізовані програмні комплекси обробки даних спостереження дозволяють знизити вимоги до підготовки обслуговуючого персоналу. Однак, БПЛА не доцільно використовувати при постійному спостереженні, особливо в несприятливих метеорологічних умовах (поривчастий вітер може привести до зносу БПЛА). Наявність великої кількості птахів на території полігонів ТПВ ускладнює безаварійну експлуатацію. Електромагнітні хвилі можуть виступати дратівливим фактором, що різко змінює поведінку птахів та стає передумовою зіткнення [14]. Разом з цим, виникають проблемні питання застосування БПЛА під час безпосереднього гасіння пожеж [15].

Таким чином, виявлення пожеж на території полігонів ТПВ потребує визначення ознак осередків горіння не тільки на поверхні, а й в тілі полігону, врахування впливу метеорологічних умов, наявності похибок через забруднення повітря токсичними продуктами розкладу відходів на шляху спостереження, а також теплових перешкод 3 боку працюючої техніки, яка може спричинити хибні сигнали осередків загорянь.

Мета дослідження полягає у запропонуванні ефективного способу виявлення пожеж на території полігону ТПВ при несприятливих метеорологічних та надзвичайних умовах, що наддасть належну інформаційну підтримку прийняття управлінських рішень із локалізації та ліквідації факторів небезпек із мінімальним впливом на довкілля та людей. Об'єктом дослідження є ймовірна пожежа на території полігону ТПВ.

Для досягнення поставленої мети використовувався системний підхід та аналіз наявних матеріалів з тематики роботи в статистичній звітності, засобах масової інформації, науковій літературі.

Результати досліджень. Забезпечення належного рівня техногенно-екологічної безпеки полігонів ТПВ включають в себе: постійний контроль за точним дотриманням технологічного регламенту утилізації відходів (якісний та кількісний склад відходів, роботи по нагромадженню, ізоляції, зволоженню); постійний контроль за станом транспортних засобів, інженерних споруд, комунікацій; контроль навколишнього середовища (підземних і поверхневих водних об'єктів, атмосферного повітря, ґрунтів і рослин, шумового забруднення в зоні можливого негативного впливу). Контроль навколишнього природного середовища переважно заснований на неавтоматизованому зборі та обробленні інформації з використанням лабораторно-хімічних методів відбору та аналізу проб здебільшого для статистичної звітності. Визначення ознак осередків горіння та виявлення пожеж не передбачені.

Процес горіння виникає внаслідок наявності горючої речовини в відповідному стані (концентрації), окислювача, що здатен вступати в хімічну реакцію, джерела займання з достатньою енергією для здійснення реакції займання горючої суміші. Полігон є місце, де акумулюється велика кількість горючих матеріалів, що різняться за морфологічним, фрракційним, хімічним складом, щільністю та вологістю. А джерелами займання можуть бути: відкритий вогонь внаслідок необережного або цілеспрямованого підпалу, гарячі поверхні, електрична дуга або іскри, електростатичний розряд, атмосферний розряд (блискавка), механічне тертя або контактна іскра, адіабатичне стиснення або ударна хвиля. Також загоряння можливо в результаті теплового, хімічного або мікробіологічного самозаймання відходів.

Будь-яка пожежа завжди є наслідком дії причин, розслідування яких являє собою проблему, оскільки $€$ реальна загроза знищення слідів обставин й умов її виникнення та особливості розвитку. Усі причини, через які виникають надзвичайні ситуації техногенного характеру можна розділити на антропогенні (внаслідок людського фактору) та природні (табл. 1).

У багатьох випадках антропогенна діяльність призводить до зниження стійкості об'єктів до дії природних фракторів, що збільшує небезпеку вторинних техногенних надзвичайних ситуацій. Будь-яка з надзвичайних ситуацій може стати причиною виникнення іншої.

Процес розкладання ТПВ характеризуються нерівномірним нагрівом, нестаціонарністю та неоднорідністю теплового випромінювання. Зазвичай, температура в тілі полігону становить $30-40^{\circ} \mathrm{C}$ [16]. Біохімічне розкладання підвищує температуру відходів до $40-70^{\circ} \mathrm{C}$, що активізує процеси хімічного окислення і веде до подальшого підвищення температури [17]. Виникнення пожеж пов'язані 3 недостатнім відтоком тепла з товщі відходів. Пожежобезпечні умови захоронення відходів характеризуються явною відсутністю наростання температур. Тенденція наростання температури свідчить про підвищення небезпеки, причому, якщо надати кисню доступ в товщу відходів, де відбувається піролітичне розкладання, може статися вибух 3 активним виділенням токсичних хімічних речовин. Територія полігону несе в собі небезпеку навіть після виведення з експлуатації ще на протязі тривалого періоду, що пов'язано $з$ постійним та неконтрольованим протіканням біохімічних процесів розкладання. Саме тому закритті полігони повинні підлягати моніторингу. 
Таблиця 1. Причини виникнення небезпеки на полігонах ТПВ та територій навколо них

\begin{tabular}{|c|c|c|}
\hline 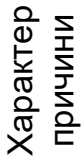 & Вид причини & $\begin{array}{c}\text { Фактори виникнення } \\
\text { причини }\end{array}$ \\
\hline \multirow[t]{2}{*}{ 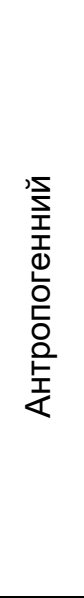 } & $\begin{array}{c}\text { Організаційно- } \\
\text { технічні при не- } \\
\text { справності/не- } \\
\text { відповідно- } \\
\text { сті/порушені }\end{array}$ & $\begin{array}{l}\text { проектувальних вишу- } \\
\text { кувань, технологічного } \\
\text { процесу, експлуатацій- } \\
\text { них вимог, системи мо- } \\
\text { ніторингу, вимог поже- } \\
\text { жної безпеки, охорони } \\
\text { праці, трудової дисцип- } \\
\text { ліни, інженерних кому- } \\
\text { нікацій, технологічного } \\
\text { обладнання, транспор- } \\
\text { тних засобів }\end{array}$ \\
\hline & Соціальні & $\begin{array}{l}\text { неуважність, недба- } \\
\text { лість, цілеспрямова- } \\
\text { ний підпалу у власних } \\
\text { інтересах }\end{array}$ \\
\hline \multirow{5}{*}{ 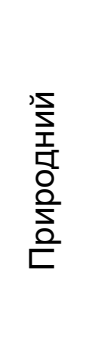 } & Метеорологічні & $\begin{array}{l}\text { підвищена кількість } \\
\text { опадів, підвищена тем- } \\
\text { пература повітря, ат- } \\
\text { мосферернии розряд }\end{array}$ \\
\hline & Гідрологічні & повінь, цунамі \\
\hline & Геологічні & $\begin{array}{l}\text { виверження вулкану, } \\
\text { зсув }\end{array}$ \\
\hline & Пожежі & лісові, польові, степові \\
\hline & Космічні & падіння небесних тіл \\
\hline
\end{tabular}

Рішення завдань виявлення пожежонебезпечної ситуації, з точки зору радіофрізики, ґрунтуються на виявленні аномальної радіо-яркістної або термодинамічної температури. Енергія відходів, яка випромінюється та сканується дистанційними приладами, безпосередньо залежить від температури. Чим вище температура, тим інтенсивніше світіння в інфрачервоному і більше випромінююча здатність в мікрохвильовому діапазонах довжин хвиль.

Пропонується спосіб виявлення пожеж на території полігону ТПВ (рис. 1) полягає в спостережені тепловізійною камерою, відеокамерою, мікрохвильовим радіометром, що розташовуються паралельно один одному на скануючій платформі з панорамною можливістю огляду. Для постійного автоматичного спостереження «на місцях» перспективно та відносно дешево використовувати вишки. Вишки представляють собою легко монтовану металеву каркасну конструкцію, де радіус огляду жорстко обмежений висотою вишки і кількістю таких споруд. Під час експлуатації даної технічної системи керівництво об'єкту повинно серйозно ставитись до проблеми перебування сторонніх осіб на території полігону ТПВ. Сторонні особи своїми діями можуть створити загрозу для експлуатації вишки спостереження та дистанційних приладів.

Тенденція наростання температури після $70^{\circ} \mathrm{C}$ в масиві $з$ відходами та на поверхні після $40^{\circ} \mathrm{C}$ на полігоні ТПВ свідчить про появу пожежонебезпечних зон, які можна виявити за спектральною оцінкою зображень отриманих за допомогою обраних дистанційних приладів спостереження. Отримані результати спостереження (зображення) в інфрачервоному, видимому, мікрохвильовому діапазонах спільно з даними кутовогоазимутального вимірювача напрямку осей приладів надходять до головного серверу. Шляхом накладання, співставлення даних в денний час доби при роботі техніки з нічним часом, а також врахування окремих чисельних вимірів рівня тепла/шуму відбувається фрільтрування й виключення теплових перешкод з боку працюючої техніки з прив'язкою до географрічних координат та відображенням на електронній карті об'єкту. Дані виводяться на монітор оператора у вигляді окремих та накладених зображень. Контролер управління дає можливість вибрати напрямок сканування. Виключення теплових перешкод та використання, як мінімум двох точок спостереження, дає змогу підвищити вірогідність виявлення осередків горіння.

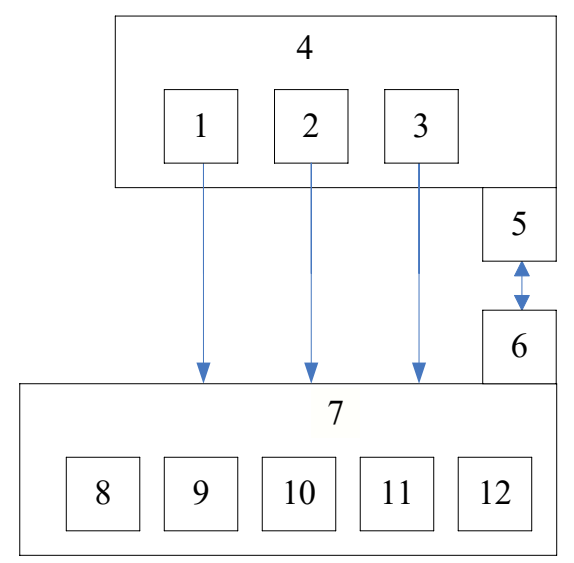

Рис. 1. Схема запропонованого способу виявлення пожеж на території полігону ТПВ:

1 - тепловізійна камера; 2 - відеокамера;

3 - мікрохвильовий радіометр; 4 - скануюча платформа; 5 - кутовий-азімутальний вимірювач; 6 - контролер управління; 7 - головний сервер; 8 - зображення тепловізійної камери; 9 - зображення відеокамери; 10 - результати мікрохвильового спостереження; 11 - накладені зображення тепловізійної камери та відеокамери;

12 - накладені результати спостереження від всіх дистанційних приладів 
Спостереження в різних діапазонах довжин хвиль надає картину зон зі стабільною і наростаючою температурою: виникнення підповерхневої пожежі з/без переходу до поверхневої або тільки поверхневої, наприклад, від зовнішнього джерела запалювання. Накладання одна на одну зображень підвищує інформативність виявлення пожежі на території полігону ТПВ, а саме:

- тепловізійне зображення 8 показує поверхневий розподіл температур (виявлення поверхневої пожежі);

- відеозображення 9 дає змогу виявити пожежу по відкритому вогню та стовпу диму, проаналізувати причину, місце небезпечної зони, розпізнати транспортні засоби, що створюють теплові/шумові перешкоди у вигляді помилкового джерела пожежі;

- результати мікрохвильового радіометру 10 показують розподіл температур в товщі відходів (виявлення підповерхневої пожежі при відсутності явних поверхневих ознак, незалежно від метеорологічних умов);

- накладання тепловізійного та відеозображення 11 наглядно дозволяє спостерігати поверхневий розподіл температур у видимому спектрі (кадрі), не перемикаючись між режимами відображення;

- накладених результатів спостереження від всіх дистанційних приладів спостереження 12 наглядно дозволяє спостерігати загальну пожежонебезпечну ситуацію не перемикаючись між режимами відображення.

Також можна передбачити передачу даних виявлення пожежі від головного серверу об'єкту до центрального пункту оперативної диспетчерської служби Головного управління Державної служби України з надзвичайних ситуацій регіону, де знаходиться полігон ТПВ. Це надасть реальну картину про стан небезпеки об'єкту, суттєво знизить приховання фракту пожежі та облегшить розслідування причин виникнення небезпеки.

Висновки. Запропонований ефективний спосіб виявлення пожеж на території полігону ТПВ в несприятливих метеорологічних та надзвичайних умовах, що надає належну інформаційну підтримку прийняття управлінських рішень із локалізації та ліквідації факторів небезпек із мінімальним впливом на довкілля та людей. Спосіб полягає у спостережені території полігону тепловізійною камерою, відеокамерою, мікрохвильовим радіометром, які розташовуються паралельно один одному на вишці 3 можливістю панорамного огляду. Отримані результати спостереження (зображення) в різних спектральних діапазонах довжин хвиль спільно з даними кутового-азимутального вимірювача напрямку осей приладів надходять до головного серверу об'єкту. Шляхом накладання, співставлення даних відбувається фрільтрування й виключення теплових перешкод. Виключення теплових перешкод та використання, як мінімум двох точок спостереження, дає змогу підвищити вірогідність виявлення осередків горіння. Це створює інформаційну підтримку ведення безпечної та ефективної тактики локалізації та ліквідації пожежі.

Подальші дослідження спрямовані на обґрунтування і розрахунок робочого діапазону довжин хвиль мікрохвильового радіометру та підтвердження економічної ефрективності запропонованого способу виявлення пожеж на полігонах ТПВ.

\section{Література}

1. Міністерство регіонального розвитку, будівництва та житлово-комунального господарства [Электронный ресурс]. - Режим доступа: http://www.minregion.gov.ua/.

2. Рашкевич Н.В. Дослідження небезпеки продуктів розкладання в місцях депонування твердих побутових відходів [Текст] / Н.В. Рашкевич, К.О. Цитлішвілі // Вісник КрНУ ім. Михайла Остроградського. - Вип. № 3/2018(110). - С. 97-102. - DOI: 10.30929/1995-0519.2018.3.97-102.

3. Municipal waste by waste operations. Eurosta [Электронный ресурс]. - Режим доступа: http://a ppsso.eurostat.ec.europa.eu /nui/show.do?dataset= env_wasmun\&lang=en.

4. Korrespondent.net. Всі новини «свалка» на сайті Korrespondent.net [Электронный ресурс]. Режим доступа: http://korrespondent.net/tag/3441/.

5. Аналіз масиву карток обліку пожеж. Український науково-дослідний інститут цивільного захисту [Электронный ресурс]. - Режим доступа: http: // undicz.dsns.gov.ua/ua/Analiz-masivu-kartokobliku-pozhezh.html.

6. World Fire Statistics. International Association of Fire and Rescue Service. - Режим доступа: http: //www.ctif.org/ctif/world-fire-statistics.

7. Рашкевич Н.В. Аналіз ефективності застосування способів запобігання надзвичайних ситуацій на полігонах депонування відходів [Текст] / Н.В. Рашкевич // Вісник НТУ «ХПІ». Серія: Механіко-технологічні системи та комплекси. - Х.: НТУ «ХП।», 2017. - № 33(1255). - С. 121-126.

8. Пат. 2534827 C2, РФ, МПК G08B 13/196 (2006.01). Способ видеонаблюдения открытого пространства с контролем пожарной опасности / С.В. Бобков, П.В. Воднев, А.А. Лукьяница, С.С. [и др.]; патентообл.: ЗАО «НТК». - № 2013116631/08; заявл. 12.04.2013; опубл. 10.12.2014, бюл. № 34 .

9. Пат. UA 78906, U Україна, МПК G08B 13/18 (2006.01). Спосіб раннього виявлення загорянь на основі аналізу інтенсивності відбитого лазерного випромінювання / Г.М. Доля, А.М. Катунін, О.С. Литвинова [та ін.]; патентовл.: Харківський 
університет повітряних сил ім. І. Кожедуба. - № u 2012 09055; под. 23.07.2012; публ. 10.04.2013, бюл. № 7.

10. Пат. 2423160 C1, РФ, МПК G08B 13/18 (2006.01), А62C 3/02. Способ дистанционного обнаружения лесных пожаров / В.В. Зуев; патентообл.: ИМКЭС СО РАН. - № 2010118042/12; заявл. 05.05.2010; опубл. 10.07.2011, бюл. № 19.

11. Пат. 16211958 А1, СССР, МПК А62С 3/02. Способ диагностики лесного пожара / А.И. Сухинин, Б.А. Хребтов.; патентообл.: Институт леса и древесины им. В.Н.Сукачева. - № 4659896/12; заявл. 09.03.1989; опубл. 23.01.91, бюл. № 3.

12. Пат. 128973 U, Україна, МПК (2018.01) A62C 3/02, G01V 3/16 (2006/01), G01V 8/00. Спосіб виявлення пожеж на полігонах твердих побутових відходів / С.О. Вамболь, В.В. Вамболь, Г.М. Резніченко [та ін.]; патентовл.: НУЦЗ України. - № 201805655; завл. 21.05.2018; опубл. 10.10.2018, Бюл. № 19.

13. Чумаченко С.М. Аналіз ефективності застосування безпілотної авіації в надзвичайних ситуаціях агропромислового комплексу України [Електронний ресурс] / С.М. Чумаченко, Л.А. Пісня, І.А. Черепньов. -С. 602-612. - Режим доступу: http://irbis-nbuv.gov.ua/cgibin/irbis_nbuv/cgiir bis 64.exe?C21CO...

14. Птицы как фрактор опасности авиатранспорта. Краткий исторический обзор и постановка задачи [Текст] / В.Ю. Дубницкий, Г.В. Фесенко, И.А. Черепнев [та ін.] // Інженерія природокористування. - 2018. - №1(9). - С. 115-131.

15. Мосов С.П. Застосування безпілотних літальних апаратів для дистанційного зондування пожеж і місць їх імовірного виникнення [Текст] / С.П. Мосов // Пожежна безпека: теорія і практика. - Черкаси: АПБ ім. Героїв Чорнобиля, 2015. - № 19. - C. 100-105.

16. Батракова Г.М. Моделирование переноса и рассеивания в атмосферном воздухе метана, эмитированного с территории захоронения твердых бытовых отходов [Текст] / Г.М. Батракова, М.Г. Бояршинов, В.Д. Горемыкин // Вестник Воронежского университета. Геология. - 2005. - № 1. - C. 256-262.

17. Получение свалочного газа - экономия первичных природных энергоресурсов [Текст] / А.М. Шаимова, Л.А. Насырова, Г.Г. Ягафрарова, P.P. Фасхутдинов // Сб. тезисов Международной научно - практической конференции «Нефтегазопереработка и нефттехимия». - Уфра, 2006. - C. 246-248.

\section{References}

1. Ministerstvo rehionalnoho rozvytku, budivnytstva ta zhytlovo-komunalnoho hospodarstva. - URL: http://www.minregion.gov.ua/.
2. Rashkevych N.V. Doslidzhennia nebezpeky produktiv rozkladannia $v$ mistsiakh deponuvannia tverdykh pobutovykh vidkhodiv [Tekst]/ N.V. Rashkevych, K.O. Tsytlishvili // Visnyk KrNU im. Mykhaila Ostrohradskoho. - Vyp. №3/2018(110). - S. 97-102. - DOI: 10.30929/1995-0519.2018.3.97-102.

3. Municipal waste by waste operations. Eurosta. - URL: http://appsso.eurostat.ec.europa.eu /nui/show.do?dataset=env_wasmun\&lang=en.

4. Korrespondent.net. Vsi novyny «svalka» na saiti Korrespondent.net. - URL: http://korresponden t.net/tag/3441/.

5. Analiz masyvu kartok obliku pozhezh. Ukrainskyi naukovo-doslidnyi instytut tsyvilnoho zakhystu. - URL: http://undicz.dsns.gov.ua/ua/Ana liz-masivu-kartok-obliku-pozhezh.html.

6. World Fire Statistics. International Association of Fire and Rescue Service. - URL: http://www.c tif.org/ctif/world-fire-statistics.

7. Rashkevych N.V. Analiz efektyvnosti zastosuvannia sposobiv zapobihannia nadzvychainykh sytuatsii na polihonakh deponuvannia vidkhodiv [Tekst] / N.V. Rashkevych // Visnyk NTU «KhPI». Seriia: Mekhaniko-tekhnolohichni systemy ta kompleksy. - Kh.: NTU «KhPI», 2017. - № 33 (1255). - S. 121-126.

8. Pat. 2534827 C2, RF, MPK G08B 13/196 (2006.01). Sposob videonabljudenija otkrytogo prostranstva s kontrolem pozharnoj opasnosti / S.V. Bobkov, P.V. Vodnev, A.A. Luk'janica, S.S. [i dr.]; patentoobl.: ZAO «NTK». - № 2013116631/08; zajavl. 12.04.2013; opubl. 10.12.2014, bjul. № 34 .

9. Pat. UA 78906, U Ukraina, MPK G08B 13/18 (2006.01). Sposib rannoho vyiavlennia zahorian na osnovi analizu intensyvnosti vidbytoho lazernoho vyprominiuvannia / H.M. Dolia, A.M. Katunin, O.S. Lytvynova [ta in.]; patentovl.: Kharkivskyi universytet povitrianykh syl im. I. Kozheduba. - № u 2012 09055; pod. 23.07.2012; publ. 10.04.2013, biul. № 7 .

10. Pat. 2423160 C1, RF, MPK G08B 13/18 (2006.01), A62C 3/02. Sposob distancionnogo obnaruzhenija lesnyh pozharov / V.V. Zuev; patentoobl.: IMKJeS SO RAN. - № 2010118042/12; zajavl. 05.05.2010; opubl. 10.07.2011, bjul. № 19.

11. Pat. 16211958 A1, SSSR, MPK A62C 3/02. Sposob diagnostiki lesnogo pozhara / A.I. Suhinin, B.A. Hrebtov.; patentoobl.: Institut lesa i drevesiny im. V.N.Sukacheva. - № 4659896/12; zajavl. 09.03.1989; opubl. 23.01.91, bjul. № 3 .

12. Pat. 128973 U, Ukraina, MPK (2018.01) A62S 3/02, G01V 3/16 (2006/01), G01V 8/00. Sposib vyiavlennia pozhezh na polihonakh tverdykh pobutovykh vidkhodiv / S.O. Vambol, V.V. Vambol, H.M. Reznichenko [ta in.]; patentovl.: NUTZ Ukrainy. - № 201805655; zavl. 21.05.2018; opubl. 10.10.2018, Biul. № 19 .

13. Chumachenko S.M. Analiz efektyvnosti zastosuvannya bezpilotnoyi aviatsiyi $v$ nadzvychay-
Інженерія природокористування, 2019, №3(13), с. 102 - 109 Engineering of nature management, 2019, \#3(13), p. 102 - 109 
nykh sytuatsiyakh ahropromyslovoho kompleksu Ukrayiny [Elektronnyy resurs] / S.M. Chumachenko, L.A. Pisnya, I.A. Cherepnov. - S. 602-612.

14. Ptitsy kak faktor opasnosti aviatransporta. Kratkiy istoricheskiy obzor i postanovka zadachi [Tekst] / V.Yu. Dubnitskiy, G.V. Fesenko, I.A. Cherepnev [ta ín.] // Ínzheneríya prirodokoristuvannya. 2018. - №1(9). - S. 115-131.

15. Mosov S.P. Zastosuvannya bezpilotnykh litalnykh aparativ dlya dystantsiynoho zonduvannya pozhezh i mists yikh imovirnoho vynyknennya [Tekst] / S.P. Mosov // Pozhezhna bezpeka: teoriya i praktyka. - Cherkasy: APB im. Heroyiv Chor- nobylya, 2015. - № 19. - S. 100-105.

16. Batrakova G.M. Modelirovanie perenosa i rasseivanija $v$ atmosfernom vozduhe metana, jemitirovannogo $s$ territorii zahoronenija tverdyh bytovyh othodov / G.M. Batrakova, M.G. Bojarshinov, V.D. Goremykin // Vestnik Voronezhskogo universiteta. Geologija. - 2005. - № 1. - S. 256-262.

17. Poluchenie svalochnogo gaza - jekonomija pervichnyh prirodnyh jenergoresursov / A.M. Shaimova, L.A. Nasyrova, G.G. Jagafarova, R.R. Fashutdinov // Sb. tezisov Mezhdunarodnoj nauchno - prakticheskoj konferencii «Neftegazopererabotka i neftehimija». - Ufa, 2006. - S. 246-248.

\section{Аннотация}

\section{Способ обнаружения пожаров на территории полигона твердых бытовых отходов}

\section{Н.В. Рашкевич, І.А. Черепньов, И.А. Ковалев}

В ходе работы отмечена техногенная опасность полигонов твердых бытовых отходов (ТБО), которая связана с возникновением поверхностных и подповерхностных пожаров. Для своевременного предупреждения возникновения и распространения пожара нужно определять горения не только на поверхности, но и внутри тела полигона. Установлено, что существующие способы выявления информационных признаков пожара при неблагоприятных метеорологических или чрезвычайных условиях характеризуются низкой оперативностью, достоверностью, полнотой.

Предложен способ обнаружения пожаров на территории полигона ТБО. Способ реализуется с помощью тепловизионной камеры, видеокамеры, микроволнового радиометра, которые располагаются параллельно друг другу на вышке с возможностью панорамного обзора. Результаты наблюдения приборов в разных спектральных диапазонах длин волн совместно с данными углового-азимутального измерителя направления осей поступают к главному серверу, где путем наложения и сопоставления подлежат фрильтрации и исключению тепловых помех. Исключение тепловых помех и использования, как минимум двух точек наблюдения, повышают вероятность обнаружения очагов горения. Таким образом, реализация предлагаемого способа обеспечивает в автоматическом режиме обнаружения очагов пожаров на ранней стадии их возникновения и информационную поддержку принятия управленческих решений локализации и ликвидации факторов опасностей с минимальным воздействием на окружающую среду и людей.

Ключові слова: пожар, полигон твердых бытовых отходов, дистанционные приборы наблюдения, тепловизионная камера, видеокамера, микроволновый радиометр.

\section{Abstract}

\section{Method of fire detecting at a municipal solid waste landfill}

\section{N.V. Rashkevich, I.A. Cherepnev, I.O. Kovalev}

In the course of researching the anthropogenic danger of municipal solid waste landfills has been noted. The danger is due to the occurrence of surface and sub-surface fires. Timely warning of the occurrence and spread of a fire depends on the definition of signs of combustion, not only on the surface, but also inside the body of the landfill. Existing methods of detecting information signs of a fire under adverse weather conditions or extreme conditions are characterized by low efficiency, reliability, completeness.

The method of fire detecting at a municipal solid waste landfill has been proposed. It is realized by a thermal imaging camera, a video camera, a microwave radiometer arranged parallel to each other on a tower with the possibility of panoramic viewing. The results of the device observations under the different spectral bands of wavelengths in conjunction with the data of the angular-azimuthal axis direction meter arrive at the 
main server. Surveillance results of devices by overlaying and comparing are subject to filtering and elimination of thermal impediments. Exclusion of thermal barriers and the use of at least two observation points increase the likelihood of detecting combustion cells. Thus, the realization of this method will provide automatic detection of fire cells at their early as occurrence stage and informational support for management decision for localization and elimination of hazards with minimal impact on the environment and people.

Keywords: fire, municipal solid waste landfill, remote monitoring devices, thermal imaging camera, video camera, microwave radiometer.

\section{Бібліографічне посилання/ Bibliography citation: Harvard}

Rashkevich, N., Cherepnev, I. and Kovalev, I. (2019). Method of fire detecting at a municipal solid waste landfill, Engineering of nature management, (3(13), pp. 102 - 109.

Подано до редакції / Received: 13.02.2019 